\title{
Profitability of Small-Scale Maize Production in Nigeria: A Case Study of Bichi Local Government, Kano State-Nigeria
}

\author{
Bello Nasiru Abdullahi, Frederick Kwame Yeboah, Nazeer Ahmed and Ibrahim Umar Muhammad
}

\begin{abstract}
This paper examined the profitability of smallscale maize production in the Bichi community using the multistage sampling procedure. Gross margin, OLS Multiple regression analysis, and Descriptive statistics were employed as analytical tools. A higher percentage of males $(90 \%)$ as against females $(10 \%)$ were revealed from the analytical results. The household size of the majority $(70 \%)$ was less than 11 persons per family among family households $(60 \%)$. A total of $\$ 395,355 /$ ha was earned as gross income whilst the gross margin of $\$ 201,331 /$ ha was estimated. Total variable cost and Total fixed cost estimated were $\$ 194,024 / \mathbf{h a}$ and $\$ 36,413 /$ ha respectively. With an $\mathrm{R}$-square of 0.807 , six explanatory variables positively explained the response variables according to the double log function. Farm size and labor had positive coefficients of 0.479 and 0.352 respectively which were significant at $1 \%$ and $5 \%$ level of significance respectively. Inadequate resources, pests and diseases, high labor costs, transport, insufficient storage facilities, and insufficient government support were problems affecting small maize producers in the study area.
\end{abstract}

Index Terms - Maize, profitability, small-scale, constraints, Bichi local government.

\section{INTRODUCTION}

Nigeria has many major maize-based staple food crops as part of Nigeria's essential staple food crop and also as part of the vital West African cereal crop. Maize is one of the main crops grown with a valuable source of protein, carbohydrates, vitamin $\mathrm{B}$, iron, and minerals in northern Nigeria [2].

In terms of caloric supply, maize emerges as the world's best supplier of calorie, supplying about $19.5 \%$. Maize supplies more calories than rice and wheat; with a caloric supply of about $16.5 \%$ and $15.0 \%$ respectively [18].

According to the FAOSTAT report, 20 African countries accounted for 96 percent of the continent's total maize production in 2018, with Nigeria as the continent's leading

Published on September 12, 2020.

Bello Nasiru Abdullahi, College of Finance and Economics, Gansu Agriculural University, Lanzhou-China.

(e-mail: bellonasiru1990@gmail.com)

Frederick Kwame Yeboah, College of Finance and Economics, Gansu Agricultural University, Lanzhou-China.

(e-mail: fredyk87@gmail.com)

Nazeer Ahmed, College of Finance and Economics, Gansu Agricultural University, Lanzhou-China.

(e-mail: nazeerahmedsumalani2@gmail.com)

Ibrahim Umar Muhammad, Department of Agricultural Economics, Federal

University Dutsinma, Katsina-Nigeria.

(e-mail: uimuhammad@fudutsinma.edu.ng) producer with 15 percent production output equivalent to 10.4 million tonnes. In terms of use, it is the fourth-ranked cereal crop, after rice, millet, and sorghum. In Nigeria, poultry producers use maize to prepare feeds for poultry and thousands of people also use maize to serve as their milk [9]. This is why Nigeria's demand for maize is growing steadily [11]. In 2017 Food and Agricultural organization reported that the mean maize output in Nigeria from 1990 to 2015 was nearly 4.7 million tons, but production increased to 10.5 million tons in 2017. Output rose from 8.7 percent to 22 percent, respectively from 1980 to 2003 [8]. The FAO also reported that maize production in Nigeria accounted for 61 percent of the farmland.

Small-scale farmers are Nigeria's largest agro-producers, holding farms below 10 hectares of land for agricultural production. Small-scale farmers control 80 percent of Nigeria's agricultural community, producing 80 percent- 90 percent of the country's food production with low capital rates and less government support [15]. An independent study has also established that the transition of farming from local to modern would help to evacuate rural poverty by providing more opportunities for people to work [3].

The study aims to describe the socio-economic demographics of small-scale maize producers, to determine the profitability of maize production, to analyze the relationship between the maize production output and the socio-economic characteristics of small-scale maize farmers, and to describe the constraints affecting small-scale maize production in the study area.

Yisa et al performed a Niger State-based cropping venture study of the relation between maize and sorghum profitability. The analysis has shown that mixed maize cultivation with other crops yields more profit than sole maize cultivation. The average gross profit per hectare of approximately 38378.41 was measured as maize and sorghum net farm income per hectare. The work suggested that enlightenment on mixed cropping with maize should be promoted for higher yields and returns. Additionally, modern development techniques should be implemented to reduce production costs to support the farmers' livelihoods as well as profits [19].

Other studies have also revealed that small-scale production of maize in Toto was profitable to the local government. The research carried out both the Gross Margin and the OLS Multiple Regression Analysis. It has been described that $83 \%$ of the producers were male and were at their peak age of strength [12]. The multi-regression result of the OLS showed that annual income, marital status, and farm size had positive coefficients of 1 percent and 5 
percent respectively. The return invested per naira was 2.40. Marketing problems, inadequate capital, pests and diseases, transport, and inadequate storage facilities were among the problems that hindered the production of maize. It has been suggested that subsidies should be granted to farmers. The study also suggested that extension workers should raise awareness among farmers about disease control measures. The finding of [7] reported that the production of maize using irrigation in the Ordre local government area of Oyo State was a profitable venture. $82 \%$ of the producers were found to be males with a mean age of 40 years. 76.3 percent of maize irrigation farmers were married to an average family size of 8 persons. The study suggested that the level of output should be increased for food safety in the study area, thus increasing the allocation of more inputs, labor, and land for more output.

Research conducted by [10] established that there was a 73 percent variation in maize output profit due to input inefficiency and other factors, while a 27 percent difference in profit was due to random factors. Mean, minimum, and maximum profit efficiency was 58 percent, 19 percent, and 83 percent respectively. The study analyzed that experience, group membership, household size, farmer education, and credit access were responsible for increasing the efficiency of profit while age, land tenure, and gender were responsible for reducing the efficiency of profit.

\section{MethodOLOGY}

\section{A. Study Area}

The research was conducted in the Bichi community. Bichi lies between latitude 12014'3" $\mathrm{N}$ and longitude 8014 '28" E. Bichi has a land area of $612 \mathrm{Km} 2$ with a total population of 277099 inhabitants [17]. The vegetation type of Bichi is Sudan savannah. Food crops are the most popular crops produced in Bichi. The crops are; maize, millet, and guinea corn. Other crops produced include cassava, tomato, onions, cowpea, beans, etc. Bichi has well-drained and moderately deep soil.

\section{B. Sampling Technique}

Multi-Stage sampling was used. Firstly, Maize farmers were selected from 3 district zones namely; Kwamarawa ward, Saye ward, and Kyalli due to the prevalence of the maize crop in these areas. Secondly, registered Maize farmers from these zones were gleaned from the farmers' register.

TABLE I: SAMPLING PROCEDURE

\begin{tabular}{ccc}
\hline Community & $\begin{array}{c}\text { Population } \\
\text { (maize farmers) }\end{array}$ & $\begin{array}{c}\text { Sample size } \\
\text { (registered maize farmers) }\end{array}$ \\
\hline Kwamarawa & 120 & 25 \\
Saye & 117 & 25 \\
Kalli & 203 & 40 \\
\hline Total & $\mathbf{4 4 0}$ & $\mathbf{9 0}$ \\
\hline
\end{tabular}

\section{Analytical tools}

The tools for the analysis were Gross margin, OLS multiple regression analysis, and Descriptive statistics. These analytical tools were adopted by [14]. Descriptive statistics and OLS multiple regression analysis was done using SPSS version 20 while the profitability of the venture was manually computed using the Mathematical formula:

$$
\begin{gathered}
\mathrm{GM}=\mathrm{TR}-\mathrm{TVC} \\
\mathrm{NFI}=\mathrm{GM}-\mathrm{TFC} \\
\mathrm{Ret} / \mathrm{N}=\mathrm{GM} / \mathrm{TC} \\
\mathrm{TC}=\mathrm{TVC}+\mathrm{TFC}
\end{gathered}
$$

where GM = Gross margin, NFI= Net farm income, Ret $/=$ Return per naira, $\mathrm{TC}=$ Total cost, $\mathrm{TVC}=$ Total variable cost, $\mathrm{TFC}=$ Total fixed cost

The OLS Multiple regression is mathematically expressed as:

$$
\mathrm{Yi}=\beta 0+\beta 1 \mathrm{X} 1+\beta 2 \mathrm{X} 2+\beta 3 \mathrm{X} 3+\ldots .+\beta 8 \mathrm{X} 8+\mathrm{U}
$$

$\mathrm{Yi}=$ maize output $(\mathrm{Kg})$;

$\mathrm{X} 1$ = Farmer Age (years);

X2 = Marital Status (dummy $1=$ single 2= married 3= divorced);

X3 = Education (years);

$\mathrm{X} 4$ = Gender (dummy $1=$ male $2=$ female);

$\mathrm{X} 5$ = Experience (years);

X6 = Labor (man hours);

$\mathrm{X} 7$ = Size of the farm (hectares);

$\mathrm{X} 8=$ Household size (number of persons);

$\mathrm{U}=$ Error term .

\section{RESUlTS AND DisCUSSION}

\section{A. Socio-economic Characteristics of the Respondents}

Table II describes the socio-economic demographics of small-scale maize farmers in the Bichi area of local government. The socio-economic characteristics of farmers include marital status, years of experience, educational level, age, gender, and household size. The table shows that $(34.4 \%)$ of respondents were single, $(5.6 \%)$ were divorced while $(60 \%)$ were married, similar to the findings of [12]. The married status will motivate farmers to devote themselves fully to agricultural production activities to produce the quantity of food that will sustain the lives of their households, as well as to obtain income that will help them solve other life-long financial problems. The table shows that (10 percent) of the producers were female while (90 percent) were male, showing that the majority of the farmers were male. This is in line with the findings of [1], which stated that the majority of producers were males with a total percentage (85 percent). The age distribution of respondents shows that (12.3 percent) were between the age range of 50 years and above, while (87.7 percent) of respondents were between the age range of 10 years and 50 years with a mean age of 31.1 years. The mean age is closer to the mean age findings of Issa et al. (2016) with an average age of 32 . The average age means that the producers have been very active in successfully carrying out their production activities. The table also shows that (33.3 percent) of respondents had only primary education, (16.7 percent) secondary education, (3.3 percent) tertiary education, and (46.7 percent) non-formal education. This means that farmers with formal education are more civilized in adopting innovations and farming technologies than those 
without formal education. (93.4 percent) of farmers have experience of fewer than 21 years, while ( 6.6 percent) have experience of more than 21 years. 11 years of experience has been calculated as average years of experience, similar to[16] finding that the average years of farming experience was 11 years. This means that most farmers have enough experience in maize farming. The table described that $(70$ percent) of producers had a household size of less than or equal to 10 persons, while (30 percent) of respondents had a household size of more than 11 persons. This finding contradicts the findings of [3], which stated that (70 percent) of the respondents had no fewer than 7 persons. The average household size was 8 people. This shows that family labor is available for the small-scale production of maize in the study area.

\begin{tabular}{|c|c|c|}
\hline Characteristics & Frequency & Percentage $(\%)$ \\
\hline \multicolumn{3}{|l|}{ Marital Status } \\
\hline Single & 31 & 34.4 \\
\hline Married & 54 & 60 \\
\hline Divorced & 5 & 5.6 \\
\hline Total & 90 & 100 \\
\hline \multicolumn{3}{|l|}{ Gender } \\
\hline Male & 81 & 90 \\
\hline Female & 9 & 10 \\
\hline Total & 90 & 100 \\
\hline \multicolumn{3}{|l|}{ Age } \\
\hline $10-20$ & 4 & 4.4 \\
\hline $21-30$ & 25 & 27.8 \\
\hline $31-40$ & 30 & 33.3 \\
\hline $41-50$ & 20 & 22.2 \\
\hline 51 and above & 11 & 12.3 \\
\hline Total & 90 & 100 \\
\hline \multicolumn{3}{|l|}{ Level of Education } \\
\hline Primary & 30 & 33.3 \\
\hline Secondary & 15 & 16.7 \\
\hline Tertiary & 3 & 3.3 \\
\hline Non-formal & 42 & 46.7 \\
\hline Total & 90 & 100 \\
\hline \multicolumn{3}{|l|}{ Years of Experience } \\
\hline $1-10$ & 59 & 65.6 \\
\hline $11-20$ & 25 & 27.8 \\
\hline 21 and above & 6 & 6.6 \\
\hline Total & 90 & 100 \\
\hline \multicolumn{3}{|l|}{ Household Size } \\
\hline $1-5$ & 38 & 42.2 \\
\hline $6-10$ & 25 & 2.8 \\
\hline $11-15$ & 16 & 17.8 \\
\hline 16 and above & 11 & 12.2 \\
\hline Total & 90 & 100 \\
\hline
\end{tabular}

B. Gross Margin Analysis for Maize Profitability in the Study Area

Table II shows that the total maize yield per hectare was 395355 . The total variable cost was calculated to be 194024 per hectare, while the total fixed cost was estimated to be 36413 per hectare. Fertilizer occupied a larger portion of the variable costs, with a value of 95000 per hectare showing that fertilizer was used by farmers than any other input into production. The gross margin was estimated at 201331 per hectare. The table also shows that 164.918 / ha was calculated as net farm income, while the return per naira was 0.87 . Return per naira shows that 87 kobo was earned for each additional investment made; showing that smallscale maize production in the study area was profitable. This is consistent with the finding of [12] and [11] where the gross margin was estimated at 132751.23 and the return per naira invested was estimated at 1.99 . This meant that a return of PAR2 was obtained for each PAR1 invested.

\begin{tabular}{lc}
\multicolumn{2}{c}{ TABLE III: ANALYSIS OF COSTS AND RETURNS PER HECTARE } \\
\hline \multicolumn{1}{c}{ Variables } & Cost per hectare (A/ha) \\
\hline A Returns & \\
Maize yield & 379500 \\
Maize husk & 15855 \\
Gross Income (GI) & 395355 \\
B Variable Costs & \\
$\quad$ Fertilizer & 95000 \\
Herbicides & 20000 \\
Seeds & 4000 \\
Labour & 65212 \\
Transportation & 9812 \\
Total Variable cost (TVC) & 194024 \\
C Fixed Costs & \\
Farm tools & 11743 \\
Cost of renting & 20800 \\
Interest on loans & 3870 \\
Total Fixed cost (TFC) & 36413 \\
D Total costs (TVC + TFC) & 230437 \\
GM= GI - TVC & 164918 \\
NFI $=$ GM - TFC & 201331 \\
Return per naira (Ret/A) $=$ GM/TC & 0.87 \\
\hline
\end{tabular}

C. Relationship between the Maize Production Output and the Socio-Economic Characteristics of The Maize SmallScale Farmers

Linear, Exponential, Semi-log and Double Log functions have been tested to select the best fit model. Due to the high number of significant variables, the Double Log function was chosen as the best fit model.

Table III presents the result of Double log regression. The result showed that six independent variables had positive sign coefficients, while two explanatory variables had negative sign coefficients. This shows that there is a direct link between the independent variables with a positive coefficient and the maize output. The coefficient of determination $\left(\mathrm{R}^{2}\right)$ was 0.807 , which means that the explanatory variables were responsible for an output variation of $80.7 \%$. It is analyzed that the farm size and labor force had positive coefficients of 0.479 and 0.352 respectively, which were significant at $1 \%$ and $5 \%$, respectively. The increase in farm size and labor will lead to an increase in output. The result of this double log function is in contrast to the double log result of [11] where the calculated $\mathrm{R}^{2}$ was 0.76 , indicating that the variation in the output level was accounted for by the explanatory variables in the model. The double log result also showed that only the labor force had a positive coefficient, which was significant at $1 \%$. This indicates that only labor as an independent variable has a direct relationship to output.

TABLE IV: DOUBLE LOG REGRESSION RESULT

\begin{tabular}{|c|c|c|c|c|}
\hline Variables & B & Strd Error & T-ratio & Sig \\
\hline Constant & 7.255 & 0.814 & $8.915^{* * *}$ & 0.000 \\
\hline Farmer Age & -0178 & 0.194 & $0.918^{\mathrm{NS}}$ & 0.364 \\
\hline Experience & -0.034 & 0.060 & $0.568^{\mathrm{NS}}$ & 0.574 \\
\hline $\begin{array}{l}\text { Household } \\
\text { size }\end{array}$ & 0.039 & 0.047 & $-0.830^{\mathrm{NS}}$ & 0.412 \\
\hline Gender & 0.041 & 0.071 & $0.575^{\mathrm{NS}}$ & 0.569 \\
\hline $\begin{array}{c}\text { Marital } \\
\text { status }\end{array}$ & 0.098 & 0.063 & $1.548^{\mathrm{NS}}$ & 0.130 \\
\hline Farm size & 0.479 & 0.139 & $3.432^{* * *}$ & 0.001 \\
\hline Education & 0.053 & 0.060 & $0.883^{\mathrm{NS}}$ & 0.383 \\
\hline Labor & 0.352 & 0.146 & $2.408^{* *}$ & 0.021 \\
\hline \multicolumn{5}{|c|}{$\begin{aligned} \text { Adjusted } \mathrm{R}^{2} & =0.767 \\
\mathrm{R}^{2} & =0.807\end{aligned}$} \\
\hline
\end{tabular}


D. Problems facing small-scale maize producers in the study area

Table IV shows that high labor costs, inadequate capital, transport problems, insufficient government support, pests and diseases, inadequate storage facilities were the constraints affecting small-scale maize producers in the study area. The distribution table shows that the main constraint is inadequate capital (83.33 percent). The table also shows that the second constraint (73.33 percent) was an inadequate storage facility. (55.56 percent) had insufficient government support, (50 percent) of farmers had a high labor cost problem, (35.56 percent) faced pests and diseases as a constraint, while (27.78 percent) had a transport problem. [3] identified constraints that disturb the production of maize. The constraints were inadequate storage facilities, land tenure issues, inadequate funding, climate, lack of credit, and inadequate irrigation facilities.

TABLE V: DISTRIBUTION OF SMALL-SCALE MAIZE PRODUCERS ACCORDING

\begin{tabular}{ccc}
\multicolumn{3}{c}{ TO PROBLEMS } \\
\hline Constraints & Frequency & Percentage \\
\hline Inadequate capital & 75 & 83.33 \\
Pests and diseases & 32 & 35.56 \\
The high cost of labor & 45 & 50.00 \\
The problem of \\
transportation \\
$\quad \begin{array}{l}\text { Insufficient } \\
\text { government support }\end{array}$ & 25 & 27.78 \\
Insufficient storage \\
facilities
\end{tabular}

\section{CONCLUSION}

It was reported that $90 \%$ of the farmers were males and were at their peak age of strength. The result of the Gross Margin showed that a profit of 87 kobo was obtained for every one of the projects invested; showing that small-scale maize production in the study area was profitable. From the findings of the research, the business was disturbed by so many problems. With all these problems, the business is profitable. Business profitability will help boost the economy of the study area and Nigeria in general. Maize production also has an impact on reducing the poverty rate as well as providing employment for unemployed youth in the study location. In this way, the profitability of the business must be maintained to address the problems that disturb the business. Failure to address these problems will have a direct impact on production and will, therefore, delay the profitability of the business. Furthermore, when the performance of the business is poor, it will directly create poverty and unemployment and therefore negatively affect the economy of the study area.

\section{RECOMMENDATIONS}

The following recommendations should be taken into account:

1. Farmers should join cooperative societies to have more opportunities to capitalize on loans because the lack of capital is a major constraint affecting their maize production in the study area.

2. The Government should provide production inputs at subsidized rates, in particular fertilizer, because the production of maize in the study area requires fertilizers other than any other input.

3. The Government should send extension workers to raise awareness among farmers about how to tackle pests and outbreaks of diseases, as well as to raise awareness among farmers about the adoption of new farming technologies.

\section{REFERENCES}

[1] Abdulai, S., Nkegbe, P. K., \& Donkor, S. A. (2017). Assessing the economic efficiency of maize production in Northern Ghana. Ghana Journal of Development Studies, 14(1), 123-145.

[2] Abdulaleem, M. A., FM, O., \& Kolawole, A. O.(2017) Analysis of Costs and Returns on Maize Production among Small-scale Farmers in Osun State Nigeria. Adult Education, 26, 14-4.

[3] Adams, O. K. (2018). Economic analysis of maize production in Kano State. Journal of Poverty, Investment and Development, 44, 53-56.

[4] Ater, P. I., Aye, G. C., \& Daniel, A.(2017) Analysis of Maize Value Addition among Entrepreneurs in Taraba State, Nigeria. International Journal of Environment, Agriculture and Biotechnology, 3(6), 268283

[5] Bwala, M. A., \& John, A. U. (2018). Profitability analysis of paddy production: A case of agricultural zone 1, Niger State Nigeria. Journal of the Bangladesh Agricultural University, 16(1), 88-92.

[6] CBN(2019).CentralBankofNigeria.Exchangeratebycurrency.https://w ww.cbn.gov.ng/rates/ExchRateByCurrency.asp.

[7] Ezekiel, A. A. (2016). Economic Analysis of Maize Production Among Irrigation Farmers in Offrire Local Government Area, Oyo State, Nigeria. Sociology Study, 6(3), 186-195.

[8] FAO, (2017). GIEWS - Global Information and Early Warning System: Country briefs, Nigeria. http://www.fao.org/giews/countrybrief/country.jsp?code=NGA.

[9] FAOSTAT 2018. FAO Statistical Database (online). Food and Agricultural Organization of the United Nations. Rome. http://faostat.fao.org.

[10] Gad, A. S., Cao, J., \& Yaa, O. K. (2019). A Profit Analysis Of SmallScale Maize Farmers: A Case Study In The Brong Ahafo Region Of Ghana, West Africa. Russian Journal of Agricultural and SocioEconomic Sciences, 96(12).

[11] Girei, A. A., Saingbe, N. D., Ohen, S. B., \& Umar, K. O. (2018). Economics of small-scale maize production in Toto local government area, Nasarawa state, Nigeria. AgResearch, 18(1), 90-104.

[12] Girei, A. A. Zaknayiba, D., And Onyenye, P. O.(2018). Production Function And Profitability Analysis Of Maize-Cowpea Intercropping In Nasarawa Eggon Local Government Area Of Nasarawa State, Nigeria. Journal of Agriculture and Rural Research. Vol. II, Issue I-II, 2018, pp.1-8.

[13] Issa, F. O., Kagbu, J. H., and Abdulkadir, S. A (2016). Economic factors influencing farmers' adoption of improved maize production practices in the Ikara Local Government Area of Kaduna State, Nigeria. AgResearch. 16(2):15 -24

[14] Kwaku Dei Antwi, Olumide Aborisade (2017). The profitability of Rice Production Among Small-Scale Rice Producers in Ghana. American Journal of Agricultural Science. Vol. 4, No. 1, 2017, pp. 1.

[15] Mgbenka, R. N., Mbah, E. N., \& Ezeano, C. I. (2016). A review of smallholder farming in Nigeria: Need for transformation. International Journal of Agricultural Extension and Rural Development Studies, $3(2), 43-54$

[16] Nkamigbo, D. C., Nwoye, I. I., Makwudo, E. O., \& Gbughemobi, B O. (2018). Economics of maize production in Oyi local government, Anambra State, Nigeria. International Journal of Agriculture and Biosciences, 7(2), 61-64.

[17] National Population Commission. (2006). NPC (2006). Federal Republic of Nigeria Official Gazette, 96(2).

[18] World Atlas (2017). Most Important Staple Foods in the World. Accessed May 2, 2018, from https://www.worldatlas.com/articles/most-important-staple-foods-inthe-world.html.

[19] Yisa, E. S., Nmadu, J. N., Tanko, L., \& Tsado, E. K. (2018) Comparative Analysis of the Profitability of Maize and Sorghum Based Cropping Enterprises in Nigeria State, Nigeria. Nigerian Journal of Agricultural Economics, 8(2066-2018-4630), 81-88. 


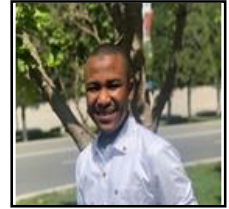

Bello Nasiru Abdullahi from Nigeria holds BSc. Agricultural Economics and Extension from Kano University of Science and Technology, Nigeria. He is currently a scholarship holder pursuing MSc. Agricultural Economics and Management at Gansu Agricultural University, Gansu Province-China.

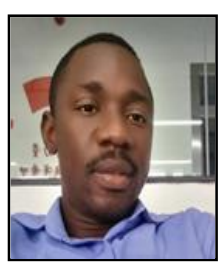

Frederick Kwame Yeboah holds a Diploma of Science in Agricultural Science and a Bachelor of Science in Agricultural Business Management from the University of Cape Coast and Kwame Nkrumah University of Science and Technology, Ghana respectively. He is currently an Economics research Student at Gansu Agricultural University, China studying MSc. Agricultural Economics and Management.

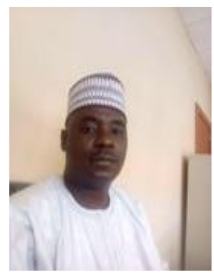

\section{Ibrahim Umar Muhammad}

Born in Kaita town located $15 \mathrm{Km}$ north of Katsina on 7th September. 1972. Graduated from Hassan Usman Katsina polytechnic with Higher National Diploma Certificate in Agricultural extension and management and Proceeded to Abubakar Tafewa Balewa University Bauchi for a postgraduate Diploma Certificate in Agricultural Economic and extension. Attend Bayero University Kano and graduated with MSc. in Agricultural Economics. Joint Katsina State local government service commission in 1995 and reach Assistant Director. Work as a Field extension office at the center for renewable energy Umaru Musa yaradua university Katsina for 5 years and joint Federal University Dutsinma as Assistant Lecturer in 2018.

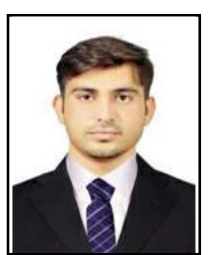

Nazeer Ahmed

At the age of 26, Nazeer is a Regional Economics fina year Masters student at the College of Finance and Economics of the Gansu Agricultural University in China. He obtained His Bachelor degree In Economics from His Home Country Pakistan at Lasbela University, Balochistan 